\title{
Kong Kristian VIII. og den danske sag i Nordslesvig.
}

Af A. $\Gamma$. Jørgensen.

(Foredrag, holdt ved det danske hojskolejubilieum i Skibelund, 8. Septbr. 1894*).

Blandt de mænd, som bør mindes med tak, nair den danske folkehøjjskole holder jubilæum, står kong Kristian VIII. i furste række. Den skole i Sorø, sum er bleven næunt s̊a ofte $\mathrm{i}$ disse dage, men som endnu hører til de fromme onsker, havde i ham sin forste og indtil den dag idag eneste ven $o g$ talsmand iblandt dem, som kunde udrette noget for dens virkeliggørelse; det var en af kongens sidste regeringshandlinger at underskrive beslutningen om, at Sorø akademi skulde omdannes til en fri og folkelig højskole. Og dette var ikke en indskydelse fra hans sidste dage. Alt 1836 havde han henledet kong Fredrik VI's opmærksombed på Grundtvigs lille skrift om „àet danske firklower", og i begyndelsen af 1838 havde denne henvendt sig til prinsen for at tale højskolens sag og straks efter skrevet sin bog: "Skolen for livet og akademiet i Sorø". Prinsen førte ham ved denne lejlighed til sin hustru, som siledes gjorde Grundtvigs bekendtskab.

*) Nedskrevet bagefter $i$ en noget fyldigere form. 
Det var dog ikke blot dette Grundtvigs store fremtidssyn, som Kiristian VIII. gik villig ind på og tilbød sigr at virkeliggøre; også den gjorte begyndelse i det små, skolen i Rødding, var han med til at fremme. Det er nu on få dage, den 14. September, 50 år siden han gæstede. Rødding højskolegard, for at se på forberedelserne her, og derved overfor både venner og fjender velkendte sig sin delagtighed $i$ det oplysningsarbejde, som her skulde pábeyyndes. Men han havde dengang alt forlængst rettet det afgørende hovedslag imod tyskhedens herredømme i Nordslesvig, som er det store vendepunkt $i$ landets nationale historie, udgangspunktet for hele den senere førte kamp. Oơ nảr vi her idag er mødtes fra begge sider af grænsen, er der god grund til at rette blikket videre ud, fra Røddings grundlaggelse for 50 år siden til hele den kongelige virksomhed for danskhedens genoprejsning i Sonderjylland, i hvilken denne skole er et enkelt led.

Vi vèd jo alle, at kong Kristian VIIl's navn bliver skudt stærkt i baggrunden eller slet ikke nævnes i denne forbindelse. Grunden hertil er let at se. Vi gentager, hvad de mænd har udtalt, som for den store almenhed stod forrest $\mathrm{i}$ kampen for den danske folkelighed, og de trålte mere end én gang i skarp modsætning til kongen, hvis gode vilje de vel ikke miskendte, men hvis holdning forekom dem vaklende og hvis evne til at bryde igennem al modstand de ingen tillid havde til. Der blev derfor talt håde ord både til ham og om ham, og han var $i$ forlge sin hoje stilling og efter selve sagens natur afskåren fra at retfærdiggøre sig ved at fremlægge de liensyn, der ofte lagde bånd pá hans virksomlied for en sag, som han blandt de forste havde grebet som et velfærds anlignende 
Kong Kristian VIII, og den danske sag i Nordslesvig. 251

for land og folk og som han til sin dødsdag viste en ubrodelig troskab. Ved hans død skyllede jo den store omvaltning hen over hans gerning, og hans navn blev givet til pris for de mest uskinsomme angreb fra alle sider. Men det turde vel nu være på tide at drage det frem på ny og yde det retfærdighed. Nar jeg skal forsøge her at gøre en begyndelse i den retning, er det, fordi jeg har kunnet gennemgå de mangfoldige breve og optegnelser af ham, som er berarede, og som gør det muligt at folge hans virksomhed og planer sa at sige fra dag til dag.

Kristian VIII. var fra ungdommen af, ja fra sin ticlligste barndom udpræget dansk. Hans fader, arveprins Fredrik, var den første kongesøn i lange tider, som havde fået en dansk opdragelse; moderen, den meget bagtalte .Juliane Marie, havde givet ham de ypperste danske larere, og han overforte denne opdragelse til sine børn. Prins Kristians danskhed var af en helt anden og langt dybere art end kong Fredrik VI's; denne var vel dansktalente, men uden narnere kendskab til dansk åndsliv og uden forestilling om nationalitetens betydning for folket 0 g dets selvstændighedsfolelse. Prins Kristian derimod tog med sine rige evner levende del i alt hvad der rørte sig i det danske folk, og han folte sig med hele sin personlighed dybt sammenvokset med alle dets minder og forhabninger, hele dets ejenilommelige natur.

Således blev han også tidlig opmriksom på betydningen af Sonderjyllants stilling mellem den danske krones lande. Da et halvt ars tid efter hans tilbagekomst fra Norge, hvor han jo lavde biret kronen i nogen tid, men derefter havde opyiret den mod at sikre rigets selvstændighed under forbindelsen med Sverige, forfatningssagen rejstes 
for Holstens vedkommende, udtalte han alt $i$ en afhandling om den politiske stilling, at ,Slesvig aldrig kan skilles fra Danmark ng forenes med Tyskland eller Holsten, eller få en forfatning anderledles end Danmarks", at "det er en dårlig vane, at Slesvig og Holsten forbindes“, at "der tales dansk i en stor del af Slesvig“, or at "det er skarleligt for rigets forfatning, at forbindelsen mellem hertugdømmerne vedbliver". Sâ klart sỉ han alt dengang på disse forholıl, ng meget vilde sikkert nu have ræret anilerledes, hvis han tidlig var bleven konge eller kongens betroede rådgiver; men kong Fredrik VI. var skinsyg på lans store evner or holdt ham udenfor regeringen, si længe det pa nogen midle kunde lade sig gøre. Først 1831, da der skulde indføres rådrivende stænderforsanlinger, fik han sæde i statsrådet.

I forår et 1832 udkom Kristian Paulsens bekendte bogr om Sønderjyllands folkeejendommelighed og statsret og han overleverede den selv til prins Kristian. Denne tog straks dens anvisninger til følge, så meget mere som de i det vasenlige fallt sammen med, hvad han alt 18:30 havde tankt sig som det rette. Alt fi dage efter talte han med de mest indflydelsesrige mænd, som havde del i hertugdømmernes styrelse, om indførelsen af dansk i de nordslesvigske kobstæder og hvor det ellers var folkespros, og han forlangte, at den nye fællesregering sâvel som den. nye hojesteret $i$ hertugdømmerne skulde deles i to afdelinger; én for hvert hertugdømme, således at der $\mathrm{i}$ den sønderjydske afieling kunde bruges bi̊le dansk og tydsk, efter befolkningens forskellige modersmål; der skulde da indføres dansk ved de lavere domstole såvel som i hele den stedlige styrelse. Denne tanke kom han under de følgende forhandlinger atter og atter tilbage til; han sogte at vinde. 
ministrene for den, han skrev et reltalende indlrog derom til kongen, han tog ordet for det i statsrådet; men alt forgæves. Vel lod præsidenten i det tyske kancelli, Otto Moltke, sig omsider overbevise, vel delte også kongen tilsynelarlende hans anskuelse og roste hans gode mening, men statsrådets flertal fulgte dor den indstilling, hvorefter regeringrens og den overste domstols fuldstændige enhed blev fastshiet, og kongen gav sit samtykke til denne skæbnesvangre ordning: .Således, skriver prinsen i sin dagbog, blev mit forslag skudt til side, og hertugdømmet Slesvig prisgivet tyskheden for lange ar, måske for bestandig!“

Efterat kong Firellik VI. i aret 1837 havde gennemxriet en hard sygdom, som nedbrod hans helbred, trådte prins Kristian mere $i$ forgrunden; fra stænderne i det folgende an skrev Hjort Lorenzen hjem: vi taler her ikke mere til Fledrik VI., men til Kristian VIII. Det var $\mathrm{i}$ denue tid han skaffede P. Kr. Koch i Haderslev tilladelse til at udgive bladet "Dannevirke", og Koch udtaler $\mathrm{i}$ den anledning ,det glade og herlige håb, som vi i stilhed gøre os, om de kommende dage til Deres kongelige højhed." Ved denne tid var det ogsa Grundtrig henvendte sig til prinsen om den kongelige højsliole i Snrø. Nogen tid efter begyndte syv Slesvigere i Kobenhavn at samle bøger or penge til oprettelsen af danske bogsamlinger i Nordslesvig, og prins Kristian hørte til de nest gavmilde deltagere $i$ denne virksomhed.

I sommeren 1838 vedtog de sønderjydske stænder et forslag om at opfordre kongen til at forelægge lovforslag om indfyrelsen af dansk rets- og orrighedssprog overalt, Jvor det var kirke- og skolesprog, det vil sige: på landet ned til Flensborg fjord. Dog sliulde hverken overretterne 
eller regeringen have dansk forretbingssprog, ej heller skulde det bruges af sagforerne. Indforelsen skulde forega straks, hvor embedsmændene kunde det, de andre steder efterhånden ved embedsskifte. Dette blev vedtaget med 21 stemmer mod $18 \mathrm{og}$ stottedes, foruden af forslagstilleren Nis Lorenzen Lilholt, af professor Falck i Kiel, som var forlt Nordslesviger, og af den frisinderle købmand Hjort Lorenzen af Haderslev. Næsten enstemmig foresloges det samtidig at indlyre tre timer tysk som skolefar $\mathrm{i}$ alle de dauske skoler. Næpje rar strnderforsamlingen sluttet, fur der imidlertid rejstes en stærk bevægelse mod dette forslag; mindretallet, hrortil hertugen af Argustenborg horte, besluttede at kæmpe imod det, nâl ct lovforslag $i$ den retning fremkom, og der dannede sig liort efter et fast sluttet politisk parti med det formal for fremtiden at optræde med storre kraft og efter en samlet plan. For forste gang opstilledes hos os den velbekendte parkimentarikke lære, at et forslag ikke skal behandles efter som det i sig selv er gavnligrt eller retfardigt, men efter som det passer ind $\mathrm{i}$ de politiske forhold og stillingen mellem regering og reprosentation. Alle var da ogsa enige $i$, at sprogsagen endnu ikke red denne lejlighed vilde have fundet sin afgørelse, dersom kong Fredrik VI. havde oplevet den nreste stænderforsamling, da han noppe vilde have forelisgt et dertil sigtende lovforslag; i alle tilfælite vilde det rwe bleven forkastet af stænderne.

Men forinden man kom sâ vidt, besteg liong Kristian VIII. tronen, og et halvt år efter ordnede han sagen u:len at tage standerne på råd, ved et kongeligt reskript til regeringen i Slesvig, det kákaldte surogreskript af 14 . Maj 1840. Herved toges stændernes forslag af 1838 til folges. 
dng således at indførelien af dansk fastsattes til no.tkommende nyîr for alle embedsmænd, sivel som for sagforere; kunde nogen ikke efterkomme dette pâbud, skulde der derom gyres indberetning til nærmere foranstaltning. Endvidere blev det pailagt regreringen at underssge, om ikke det danske talesprog strakte sigr længere mod syd end skolesproget, og særlig om sprogforholdene i købstrederne, hvor skolesproget var tysk. Endelig indførtes de begærede tre timer tysk i Nordslesvig, dog udenfor skoletiden og siledes, at det blev en frivillig sag for forældrene, om de vilde lade børnene deltage $\mathrm{i}$ dem.

Denne afgorelse af sprogstriden vakte et overordenligt røre. Det var et resolut og gennemgribende skridt af den enevældige konge, gjort imod statsriudets rîd; selv Otto Moltke og Ørsted ansi det for alt for voveligt, men for kongen var det et længe overvejet og fast besluttet forset. Det var et brud med århundreders politik i Sønderjylland, udgangspunktet for en fuldstændig opgørelse mellem dansk og tysk, der matte føre til sprogenes ligeberettigelse i alle forhold. Alle nogenlunde fremskuende mænd måtte kunne se dette; kongen var $\mathrm{i}$ den henseende aldeles på det rene med sirg selv.

Der rejstes straks en forbitret modstand mod reskriptet: af embedsmændene, der begyndte med at erklære, at de ikke liunde bringe det til udforelse; af adel og godsejere, der pristod, at de havde ret til at varetage rets- og gvrighedssager $i$ det sprog, de selv onskede, og af sagførerne, der ikke vilde skrive dansk og senere dannede en forening, hvis medlemmer forpligtede sig til ikke at føre danske sager videre for overretterne. Stænderforsamlingen, som kort efter trådte sammen, vedtog med 33 stemmer mod 9 
at tilrâde reskriptets ophrevelse, og selv dette mindretal forsikrede, at det ikke ønskede at føre sagen vider'e: man vilde ikke have dansk ved de højere avtoriteter, man vilde ikke flytte sproggræensen mod syd eller ud over staderne, og man ønskede intet fuellesskab med Danmark. Kongen lod sig imidlertid ikke bringe fra sin rej; han indforte vel enkelte lempelser, især for sagfgrerne, ler jo i god tro havde bosat sig $i$ et land med tysk retssprog og ikke uclen store vanskeligheder kunde tilegne sig et nyt, hvis juridislie udtryksmåde var dem fremmed, selv om de kunde tale det sønderjydske folkesjrog, - men gennemførelsen af den hele foranstaltning bler ikke, som selv højtstionde embedsmænd tilrådede, stillet $\mathrm{i}$ bero; den skulde og måtte fastlıoldes.

Men sprogreskrintet havde enduu en anden folge; det fremkaldte et omslag i stemningen i Nordslesvig. Peter Hjort Lorenzen havde alt $i$ enkelte sporgsmal begyndt at fjerne sig fra sine frisindede meningsfaller, blanit hville han indtog en meget fremskudt plads; han var en af Slesvigholstenernes bedste mænd. Endnu ved Kristian VIIl's tronbestigelse havde han dog foranlediget afsendelsen af en tysk adresse fra byridet i Haderslev, i hvilken der forlangtes indførelsen af en slesvigholstensk fælles-forfatning. Irort efter begyndte han at vakle i sin opfattelse af frihedens fremtidsulsigter i Danmark og i hertugdømmerne, og efter sprogreskriptets kundgørelse hældede han mere og mere til den anskuelse, at en kongevilje som den, der her havde givet sig til kende, vilde være istand til at bryde enhver modstand også $\mathrm{i}$ andre retninger. Det kom da til det bekendte omslag $\mathrm{i}$ hans politiske stilling, og med Hjort Lorenzen fulgte indflydelsesrige mænd i de andre kobstæder såvel som på landet, fremfor alle Lavrids Skau. Andre derimod tog nu mere afgiort parti for modstanderne, 
og særlig gjaldt dette hertugen af Avgustenborg. Hans tidligere venskabelige forhold til kongen kølnedes derfor efterhånden, og medens i $1840 \mathrm{og} 1841$ Hjort Lorenzen mere og mere sluttede sig til de danske og opstillede et vidtgående fremtidsprogram i national retning, ophørte efterhånden enhver politisk tankeudveksling mellem de to srogre, selv om de endnu i flere år vedblev at stå i venskabelig familieforbindelse. Når man i almindelighed også senere antog, at kongen stod under indflydelse af hertugen, var dette uden al grund; spændingen mellem dem voksede fra år til år, indtil enhver meddelelse mellem dem, også i familieforhold, ophørte.

Det samme var derimod ikke tilfældet med hertugens broder, prins Fredrik af Nør. Han var en mindre påstålig natur, stod ofte i et spændt forhold til sin broder og ønskede at spille en politisk rolle på egen hånd. Da derfor misfornøjelsen med kongens bestræbelser til bevaring og udvikling af monarkiets enhed og for det danske sprogs ret i begyndelsen af året 1842 nåede en betænkelig højde, kaldte Kristian VIII. prinsen til København for at rådføre sig med ham om den forestående hærreform, til hvilken han havde indleveret et forslag, som fandt bifald i militærkommissionen, og ved denne lejlighed overtog han embedet som statholder og lrommanderende general i hertugdømmerne. Kongen har gjort optegnelser om sine forhandlinger med ham $\mathrm{i}$ den anledning. Prinsen gjorde gældende, at det for at berolige stemningen $i$ hertugdømmerne var nødvendigt at optage en mand herfra i statsrådet, der for øjeblikket kun bestod af kongerigske ministre.*) Dette

*) Rantzau-Breitenburg, der vel formelt endnu var medlem, boede på sine godser i Holsten. 
rid fulgte Iristian VIII. ved at udnævne Reventlov Criminil, men samtidig med ham A. S. Orsted til minister. Prinsen blev statholder og general, efterat have lovet lojalt at underordne sig kongens politilk: ikke at forandre statsdelenes nuvarende ordning og de til bedste for danskheden trufne foranstaltninger; kunde lan ikke mere folge liongen, vilde han tage sin afsked. Denne udnæevnelse bidrog til at bringe ro $\mathrm{i}$ sindede i Holsten, medens hertugen. folte sig tilsidesat. I Danmark, hvor dette forlold var uhekendt, vakte den store betænkeligheder og en hidsigr opposition, idlet man tillagde statholderembedet en betydning, som det ikke havde. Efter regeringens oprettelse var nenlig alle de tidligere statholderforretninger gâele over til denne, or prinsen siger selv $i$ sine erindringer, at han ved sin tiltrxdelse egenlig blot fik afgrolelsen af sager vedrorende tilladelse til skuespil og markedsgogl. Da han hurtig table kongens tillid, fik han heller aldrig nogen egenlig iniflyclelse, on han end bevaredes $\mathrm{i}$ sin stilling si lenge som muligt for at undgå et offenligt brud. At h in havde kommandoen over de i hertugdommerne liggende troplyer, kunde ganske vist have medfort farer, hvis urolinghederne var bleven mere alvorlige; men kongen havde det jo $\mathrm{i}$ sin magt til enhver tid at flytte om imellem hærens afdelinger or derved sikre opretholdelsen af don offenlige ro.

Den skete udnavnel:e pávirliede da ej heller i mindite måde kongrens nationale politik. Han lod fremsatte forslaw om ophavelsen af toldgræensen ved Kongetien, om falles stænderkomiteer for hele monarkiet, om en fælles undervisningsdirektion m. m., og da hærreformen gennemfortes, overrakte han selv regimenterne i Rensborg deres nye 
faner, som alle var danuebrogsfaner, medens de xldre fremstillede landsdelenes våbenmærker 0.1 .

Derefter $\mathrm{kom}$ si det store sammenstod i stænderne i November 1842, da Hjort Lorenzen talte dansk. Der rejste sig en storm imod ham fra tysk side, men kongen erklarede, at det var de danske deputeredes "naturlige ret" at tale modersmålet, og at han vilde varne om denne ret. Hjort Lorenzen skrev med rette hjem: „vi har sejret!. Lort efter kom han til Kobenharn, hvor Hertallets brutale optræilen foltes som en forhanelse af selve den danske nationalitet og fremkaldte en stærk berærgelse; lan folte meget rel, at han havde bidle kongen og hans privatsekreticr Adler, salvel som enkelte af ministrene på sin side, men alle tilritdede de ham dng midehold. Kongen især had ham om at berolige stemningen, men Hjort Lorenzen afslog̣ dette, idet han pástod, at oussá sagen dermed vilde falde til ro og alt blive ved det gamle; hans opgave mittedet blive at for urolige og holde bevargelsen i live, indtil man harde opniet, hvad der var ret: fuld lighed for det danske sprog bide i standerne og red oprettelsen af lareanstalter.

Det er hekendt nok, hrorledes dette sammenstod altid er bleven fremstillet for os til nedsættelse af kong liristian VIII.; hans holdning bliver betegnet som vaklende, frygtagtiog og umandig. Ilen med stor wret. At Hjort Lorenzen onskede en hurtigere og kraftigere handling, var naturligt nok, or at man $i$ sin harme $i$ kongrerjget vilde lave den kongelige magt anvendt $i$ hele sit omfang, ligesâ; men liongen havde ogsâ andre hensyn at tage. Den historiske ubvikling er i det hele taget ikke slet så simpel og usammensat som man ofte antager, og især dengang, i det offenlige 
livs barndom, antog. Enhver stor sag, som kommer op og vil frem, moller ikke blot sin modstand, men dens venner vil ogsi som oftest dele sig i to hold. Der er noget, man kunde kalde tokammersystemet $i$ selve den naturlige udvikling. Ved folkereprasentationens deling i to kamre har man jo sogt at sikre udviklingens mest betrygende fremskriden; det ene skal føre taukerne frem, virke for dem, udbrede og uddybe dem; det andet skal indordne dem $i$ det bestaende, tillempe dem efter forholdene og søl'ge for at de ikke afstedkommer skade og brud ud over det uundquelige. Denne dobbelthed har selve livet lart os; hror et af disse led mangler, vil udviklingen enten gi̊ i stå eller skyde ucl over målet og føre til tab og tilbageslag fra anden side.

I den sonderjydske sag betegnes disse to sider pia en fyldig og saire tiltalende mide af Hjort Lorenzen og Kristian VIII. Medens den første var ung i sin danskhed, wylig omvendt og derfor hidsig på det, opfyldt af iver efter at komme sine tidligere meningsfaller, der nu hånede ham som en overlober, til livs, - var kongen jo gammel i kampen og klar over dens gradvise forlob. Medens Lorenzen var en fyrig folkefører, utilmodig efter at nå det endelire mål, hensynslos i sin optræden overfor renner og fjender, var kongen bunden ved mange og vigtige hensyn til sine andre undersåtter og andre statsformal, ligesom han af naturen og som folge af sin hoje dannelse var en hensyusfuld mand.

Det gjaldt jo om at gennemføre danskhedens sag $i$ Sonderjylland uden afgrorende brud med monarkiets tyske indbygrgere. Disse skulde lære at indsé, at det danske sprog harde en naturlig ret, som kunde gores galdende 
uden at berøve dem noget af deres. Sligt går ikke så let i virkeligheden som på papiret. 'Den dalevende slægt var opvolsset i forestillingen om hertugdømmernes enhed overfor . kongeriget, det var ingen tilsnigelse, som man har villet påstå, men desværre en kendsgerning af sørgeligste art. Sproget i Nordslesvig truede nu med at gøre brud på denne enhed og man si $i$ danskhedens sejr ikke blot et nederlag for en stor del af embedsstanden, men en begyndende opløsning af det politiske legeme Slesvig-Holsten, til forclel for Danmark.

Samtidig triadte en anden fare frem, den dobbelte arvefølge. Kongen havde fảet sin søn gift anden gang, men man mente alt nu at kunne skønne, at ogsa dette ægteskab vilde blive barnløst, måske opløses ved en ny skilsmisse. Kronen vilde da gå $i$ arv til kvindelinjen, men her stod for hertugdømmerrses vedkommende påstand mod påstand: fra dansk side holdt man med rette på, at Sønderjylland skulde følge kongerigets arvegang, medens man var uvis med hensyn til Holsten; Avgustenborgerne derimod påstod, at de i så tilfælde vilde arve begge hertugdømmer. Denne vanskelige sag anså kongen det for sin opgave at fa ordnet før sin død, da han ikke kunde gøre regning på, at det vilde lykkes for hans søn, som på grund af sit uregelmassige liv og sine lidet udviklede evner kun nød ringe tillid og anseelse blandt de store magters monarker, og det var af stor betydning ikke at ægge stemningen $i$ Holsten mere end nødvendigt for ikke at umuliggøre en mindelig overenskomst. Endvidere vidste kongen så godt. som nogen, at indførelsen af en friere forfatning $i$ allekronens lande kun var et tidsspørgsmål, og at der også. herved vilde optårne sig uoverstigelige vanskeligheder, hvis 
modsxtmingen mellem landsdelene tik lov til at udvikle sig i hele sin skarphed.

Dersom danskheden i Nordslesvig ikke havde reret til, vilde alt dette forholdsvis have varet en let sag at ordue. Man onskede ikke i Holsten at skilles fra Danmark og arvefolgens ordning vilde ingen modstand have frembaldt, da Avgustenborgerne var ilde lidte $i$ alle samfundskredse; også forfatningssagen vilde da ulen vanskelighed have kunnet bringes i orden, da frihedsmændene $i$ kongreriget og $\mathrm{i}$ hertugdømmerne fra furst af arbejdede lând i hând. Men det nationale spyrgsmảl i Nordslesvig umuligajorde forelobig enhver orerensliomst; opgaven blev at opnî en ordining uden at lade denne befolkning i stikken, at give den sin ret uden at stonle de andre fi'a sig. Nâr man allerede ved demne tid overfor Slesvinholstenernes påstand på den afgrorende grænse ved liongeảen stilledle en anden, en delingr af monarkiet ved Ejkleren, og troede at kunne gennemfore den i henhold til gamle historiske minder og statsretligre forhold, så kunde kongen ikke gå ind herpa, for der foreli en tvingende nodvendighed, men matte modsætte sig et overureh, som kun kunde føre til tab. Vilde man appellere til magten, matte det huskes, at Slesvigholstenerne havde Tyskland i ryggen, en omtvistet arvefolge og lange tiders hævd at stotte sig til.

Fra sammenstudet i Slesvig stendersal i November 1842 urlgik der magtige folkebevægelser til begge sirter. Slesvigholstenerne modsatte sigr ethvert skridt til monarkiets befæstelse, ethrert forsog på at styrke forbindelsen mellem Slesvig og Danmark. Da kongen oprettede en filial af nationalbanken i Flensborg, gjorde de piostand pil at fa en "landesbank" i Rensborg; de kræredle en tysk 
officérskole og tysk kommando i deres hærafdeling; de vilde have særskilte finanser uden toldénhed; imod indfor'elsen af danebrog i hæren satte de en ny opfunden landsfane, som de begyndte at bruge ved alle festlige lag; sangen „Schleswig-Holstein“ opstod som udtryk for modstanden imod hertugdømmernes arkkillelse og det tyske sprogs fortrængelse fra herredømmet.

Men ogsi den danske sag gjorde nu mægtige fremskridt. Prof. Clausen optrådte i Schouws "Danske ugeskirift“ til forsvar for Hjort Lorenzen og med klav på, at det danske sprogs ret skulde respekteres; grev Knutl og andre ansete mænd sluttede sig hertil, og der dannedes en forening „for dansk undervisnings fremme i Slesvig", den forening, som senere bekostedle Rødding højskole. Estrup til Kongsilal, ministerens fader, gav 16,000 kroner til oprettelsen af en larestol i slesvigsk ret ved universitetet. Grundtvig gik til kongen for at tale højskolens sag, og denne rådførte sig med Ingemann om en omdannelse af Sorø akademi. Samtidig var det pastor IIagen i Mjolden henvendte six til Ploug og Clausen, og disse mænd gjorde alvor af at udkaste planen til den folkelige højskole i Haderslev amt.

I selve Nordslesvig holdtes der som bekendt fest for Hjort Lorenzen i Sonmersted, derpå en almindelig folkefest på Skamlingsbanke, medens den slesvigske forening dannedes for at samle befolkningen under de forestående kampe.

I forairet 1844 udkom det såkaldte "sprogpatent", som foreløbig ordnede det danske sprogs forhold i stændersalen. Forsamlingen havde fraridet enhver bestemmelse herom, idet den lovede at tilstede enhver, som bevislig var ude af stand til at udtrykle sig forstieligt pai tysk, at tale 
dansk; nıen herverl kunde kongen selvfrigelig ikke larle det bero. Efter lange forhandlinger i statsrådet vedtoges det at bestemme, at enhver deputeret, „som ikke tiltroede sig at være det tyske sprog tilstrækkelig mægtig“", kunde mol'e anmellelse derom $\mathrm{i}$ det forste mole og da tale dansk; renne anmeldelse skulde tages til efterretning og kunde ilke gøres til genstand for forsamlingens skøn. Hjælpesekretærerne skulde derfor kunne dansk, men tage foredragene til protokols pa tysk. Enhver kunde stille forslag og andragender pâ dansk.

Udsterlelsen af dette patent vakte en storm i Kobenhavn, hvorfor det modtoges med ro i hertugdommerne. Lavrids Skau optrådte dog med stort mådehold overfor kongen, der forlangte, at de danske deputerede skulde indfinde sig $\mathrm{i}$ standerne $\mathrm{og}$ stille forslag dèr, hvis de wnskede en videre gående ligeberettigelse; han vilde da gå med hertil. Patentets ord forstod han silledes, at Hjort Lorenzen med rette kunde blive ved at tale dansk, da det lom an pá enhvers egret skøn, hvilke fordringer han vilde stille til sig selv og det sprog, han førte. Alle var da ogsia enige om, at de lanske deputerede burde gå til Slesvig, kun Hjort Lorenzen modsatte sig og rasede mod sine venner. Han blev vel bragt til at give efter, men forandrede $i$ sidste ojeblik sin beslutning og afgav en offenlig erklæring om ikke at kunne underkaste sig dette formentlig forsmædelige vilkâr. De andre måtte da bøjje sig for hans vilje. Men hvor langt han her havde skudt over málet, viste sig to ar efter, da han var død og de danske deputerede uden indsigelse gik til Slesvig, medens kun én af dem, Nis Lorenzen, forbeholdt sig "somme tider" at tale dansk. Da sagen dengang (1846) forelagdes i stats- 
Kong Kristian VIII, og den danslse sag i Nordslesvig. $\quad 265$

rädet, hollt alle ministre for, at der ikke var nogen grund til at gá videre, săledes som kongen onskede; selv kronprinsen (Fredrils VII.) ytrede, at "det kun var agitation, mere fremkunstlet end virkelig."

Den store bevagelse i København og kongeriget, som tik sit ultryk i en adresse med 20,060 navne, valite ganske naturligt bitre foreker hos kongen. Da prof. Schouw overrakte ham den, swarede han: „Jeg erkender gerne det patriotiske sindelag, som har fremkaldt denne adresse og som jes deler med Dem; de offenlige foranstaltninger til det danske sprogs opretholdelse i det nordlige Slesvig vidner noksom derom." IIan kunde, fortsatte han, ej her svare på en sag, som behandledes $i$ en ralgt forsamling $i$ en anden landsdel; dog vilde han ytre, at fæodrelandssindede mæud hellere má optræede forsonende end énsidig og at det er lettere at fururolige end berolige simdene: "det forste sker ved at samle underskiffer rundt om i landet, det sidste overlader De til kongen. Iog jeg vil hâbe, at kraften ikke skal fattes mig for at dette kan lykkes."

Samtidig vedtog og offenliggjorde den slesvigske foreningr en meget næroinende udtalelse („protolekstrakten“) og Lavrids Skau skrev under indtrykket af Hjort Lorenzens harme sit bekendte brev til kongen, hvori han tiltalte ham som ligemand, og som han var uforsigtig nok til ligeledes at lade komme offeulig frem. Foreningen blev herefter lukket og undersogelser anstillede, hvis forlob ikke var nær sâ heldig for bonderne, som Skau griver det udseende af i sine bekendte fremstillinger. Det er ej heller ristigt, nù man har pastiet, at der fandt et omslay sted i kongens holdning efter en samtale med Hertel og Skau la Eur, eller efter Tillisch's dod pá Gram. 
Kongen havde ikke noget rjeblik ongivet sin danske politik i Nordslesvig, om han end med rette forbitredes over den uforstand, hvormed man optrâdte imod ham. Han havde den 15. Juni, selisirs dagen efter "Dannevirkes“ udgivelse, givet sit samtykke til højskolens oprettelse i Rodding, og den 11. Juli bestemte han, at alle meddelelser fra de kongelige kollegier i Kobenhavn og fra regeringen i Slesvig til private i det danske Slesvig skulde tilstilles disse $i$ en retsgyldig dansk oversættelse, ,indtil disse avtoriteter selv kunde udfærdige dem jå dansk." Her var der altsa sat et nyt mål for modersmailets ligeherettigelse. Kort efter, $i$ månedens slutning, ankom knngen uventet til Åbenrå for at undersøge, om det var sandt, livad man pastod, at tingboger og andre protokoller endnu fortes på tysk. Han fandt, at de var danske. Det samme gentog sig i Halerslev, hvor han tog ud til tinghuset $\mathrm{i}$ Torning for at se den bekendte mindetavle om sprogreskriptet, som herredsfogden ikke havde villet give plads. Endvidere lod han sognefogderne fia Østeramtet sammenkalde for at sporge dern ul om sprogforholdene; han opfordrede dem til at holde over modersmålet i skolen, oæ klage, hris det ej blev adlydt, hvad der var bestemt. Han gennemgik alle regeringsforanstaltninger fra 1840 af og sluttede med at sige, at hvis nogen sagde, at han var nindre dansksinclet end forhen eller gik i Tyskernes ledebind, da var det åben usandhed. Derefter tog kongen til For, hvor han modtog Hertel og Skau, der bad ham om forladelse for deres overilede angreb; til Skau sagde han, at han måtte takke Gud, han havde en så nådir konge, men denne sag skulde stå ham åben, hvis han ofterc tillod sig sligt. Pât hjemvejen undersogte han ogssâ i Tondel 
tingbrgerne og tog så over Ribe, Gram ogr Rødding til Nørrejylland. Da statholderen tilbød ham ledsagelse af ryttere gennem Nordslesvig, gav han det bekendte svar: zjeg stoler trygt på det dansktalende nordslesvigske folks sindelag mod kongen, ogr når de danner en vaçt for at vogte om kongens person, si er det lige så sikkert som om jeg var omgrivet af min garde."

Atter arbejdedes der rolig videre under voksende modstand fra slesvigholstensk side, idet dog arvefølgens ordning efter Roskilde-standernes opfordring nu tråde i forgrunden. Der blev nedsat en kommission til at drofte dette spørasmål, uden at den dog kunde komme til noget resultat for det egenlige Holstens (det gamle grevskabs) vedkommende, medens alle var enige $i$ at erklære Slesvigs arvefølge $i$ - overensstemmelse med kongeloven for utvivlsom. Kommissionen fraraidede dog at lade dette fremtræele $\mathrm{i}$ en kongelig kundgørelse, sâledes som de danske stæncler havde ønsket, og statsradets flertal stottede denne mening, da det vilde være farligt at ytre tvivl on Holstens fremtid. Men kongen var bestemt på at sikre Slesvigs fremtid for alle tilfælde og førte sin mening sejright igennem i syv lange statsrådsmøder, der holdtes i uafbrudt følge i én uge. Hele statsrådet, også ఝrsted og Criminil, der til det sidste modsatte sig udstedelsen, underskrev det såkaldte „abne brev“ (af 8 .Juli 1846), som fastslog Slesvigs uadskillelige forbindelse med den danske krone. Det er et vidnesbyrd om den overlegne personlighed, den styrke i overbevisningen og den uimodståelige veltalenhed, kongen rådede over; at han trængte igennem $i$ denne sag uden at behøve at forandre sit ministeriums sammensæetning; hertugen ultalte da ogsa i sit senere forbitrede stridskrift mod ham og hans politik, 
at han havde været $i$ besiddelse af en dæmonisk magt over udmærkede mænd, si tle byjede sig for hans vilje* uden at kunne hævile deres egen overbevisning.

Udstedelsen af det åbne brev fulgtes af indsigelser $0 \mathrm{~g}$ stormende optrin i hertugdømmerne, medens kongon som sadvanligr ved denne tid opholdt sig på For. Her afskedigede lam prinsen af Nor og inddrog hans embede, medens han. satte pâlidelige mand i spidsen for regeringen pâ Gottorp og det tyske kancelli. Skønt advaret for mulige uroligheder tog han senere fra For til Slesvis, hror der forefaldt gadetumulter under hans nærværelse; derfra til Rensborg, hror han talte til garnisonen, til Neumünster, hvor det nylig var kommen til sammenstyd med tropperne, og til Plon, hvor han blev en maned med udtugter til forskellige egne i Holsten.

Den stærke bevægelse lagde sirg efterhånden $n g$ en smuk Oktoberdag vencte kongen tilhage til hovedstalen, modtagen på toldboden og Langelinje af en uoverskuelig menneskemrengde, som jublede ham imsde, fulyte ham til Amalienborg og vilde have hædret ham vel at træhke vognen. Da lan nogle aftener efter viste sig i teatret, hyldedes han $i$ en sang af Heiberg til nationalsangens toner som "son af Slijold" og blev genstand for en jublende hyldest.

Kristian VIII. havde ikke glemt sprogsagen over de andre, mere pâtrongrende sporgsmål. Viborgr-stændernes adresse on at varne om den danske nationalitet havde givet ham anleining til at forelægge let dankke kancelli, hvem det ellers ikke vedkom, dette spor'rsmål, og kancelliet lavile pấ grundlag af en virltløftig erklæring af Ørsted foreshiet, at der sliulde anstilles en undersøgelse af folke- 
sprogets granser i Sønderjylland; hvor da dansk var ublandet talesprog, skulde det indfores i skolen og styrelsen, hvor der taltes blandet dansk og tysk, skulde skolen give nogle timers undervisning i dansk og lirkesproget være blandet. Derimod frarådede kancelliet oprettelsen af danske lrreanstalter indenfor hertugdommets grænser og af et læreembed i slesvigsk ret i København, da der ikke gaves nogen sådan ret (men kun en slesvig-holstensk!). Kongen tog det første forslag til følge og pålagde regeringen på Gottorp at undersoge sprogforholdene; derimod lod han sig iklke af sit danske kancelli stanse i bestræbelsen for at fa oprettet danske dannelsesanstalter: 11. Juni 1847 toges der besteumelse om et skolelarerseminarium i Vonsbak og på ârets sidste dag om Haderslev latinskoles omdannelse i lighed med de kongerigske skoler. Dagen før havde han taget bestemmelse om Sorø frie højskole. Det var blandt hans sidste regeringshandlinger'; de stod i noje forbindelse med, hvad han dengang var fuldt optagen af, indforelsen af en fri folkelig forfatning, hvis lykkebringende folger han ansâ for noje knyttede til en rigere og friere undervisning for folkets brede lag. Overvallet af en heftig syirdom straks i begyndelsen af det folgende år, vedblev han til det sidste at sysle med de to tanker, glad ved at stå deres virkeliggorelse så nær. Da tog doden ham og en ny tid kuldkastede alle haus planer, for under ualmindelige forhold at frre de tanker, han havde villet virkeliggore lancromt og sikkert, til en hurtig og forhastet sejr.

Det var et mærkeligt liv og en stor kongegerning, som siledes bler afsluttet lige for omvaltningen 1848. Kong Kristian VIII. havde haft sin rige del i store gennemhrud af det nationale liv i alle det gamle danske riges 
lande, først i Norge, senere i Danmark og Sønderjylland, og ikke alle de mænd, som stod ved hans âbne grav, var blinde derfor. Smukt og fyldigt, om end tillige vemodigt kommer det frem i den sorgekantate af J. L. Heiberg, som blev sungen ved universitetets mindefest for ham, isser: i folgende sang:

Højt stod han stillet på fjeldet, en yngling med flagrende lok, han slog pá frihedsvældet som Moses med Arons stok: og klippens revnede sider en sprudlende bæk fornam, med vande for kommende tider, men ingen dråbe for ham!

Han stod $\mathbf{i}$ de dybe dale som mand, da lokken var brun, for fribedens nattergale han planted et skov-pavlun: og dalen til alle sider en spirende vækst fornam, med skygge for kommende tider, men ingen skygge for ham!

Dog ej furst døden ham bragte, men livet lønnende krans, thi skønhed og højhed lagde sin trofaste hånd $\mathrm{i}$ haus, og samklangs-toner omsider i folkets røst han fornam: de nå til kommende tider, men lønnede dog alt ham!

Disse „samklangs-toner" skal da også lyde her, ved!

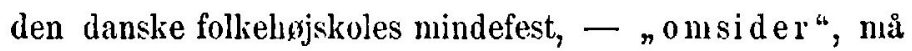
vi vel sige med digteren. Hvor forunderligt er det ikke, at for denne konge, som satte eftermælets herlighed så hojt, er der ingensteds rejst noget synligt minde; han der fik den første smukke hyldest af nordslesvigske bønder, 
Kong Kristian VIIl. og den danske sag i Nordslesvig. 271

mindetavlen i Gram herreds tingstue, der blev ødelagt i oproret, han nævnes end ilike pai Sliamlingstoxtten blandt de mænd, som har været med i kampen for modersmålets ret! Men herpâ ligger der jo ringe vægt! Hvad der derimod er af betydning for vor egen skyld, er at hans navn atter fremdrages og nævnes med ære og med tak, hvor gode danske mand bringes pấ tale, - med tak både for, hvad han fik lykke til at udrette, og hvad lan stræbte efter som sit mâl, men ikke náede!

\section{Efterskrift.}

Da foranstáende foredrag, siden det fremkom har været genstand for megen omtale, -- både stæerk tilslutning or stærk modsigelse, - kan der vare anledningr til nu, da offentliggrrelsen er bleven en del forsinket, dels at fxje en og anden nærmere oplysing til de meddelte historiske kendsgerninger, dek at ledsage det med nogle, som det forekommer mig, nærliggende betragtninger.

Det nâ dog straks bemærkes, at det kun er ganske enkelte punkter, her vil kunne berøres; en fuldstændig redegorelse og bevisforelse for min opfattelse af kong Kristian VIII. vil jo kun kunne gives i en samlet fremstilling af hans regeringshistorie.

Hvad der da først trænger til nærmere omtale, skønt jeg i min mindetale selvfølgelig ikke fandt nogen anledning til at berøre det, er den bebrejdelse mod kongen, at han manglede mandigt mod og at han var vaklende $i$ sine beslutninger. Heri er der noget sandt, men også en stor overdrivelse, og som oftest et fuldstrendirrt fejlsyn. Kristian VIII. 
var en i hojeste grad intelligent mand, og han harde alle de fortrin og fejl, som plejer at folge med intelligensens ensidige udvikling $o g$ som rort offenlige liv har at takke for så meget lys og adskillig skygrge. "Intet menneskeligt var fremmed for ham;" han fulgte sa at sige alle livets fænomener med den fuldeste interesse og den klareste forstålse, fa har haft færre fordomme på det andelige lirs omrider end han, fì har med så udholdende opmærksomhed fulgt alle samfundets rorelser i stort og smat. Skyggesiden herved er jo den, at den personlige produktivitet, evnen til selv at frembringe og handle, srækkes, betænkelighederne fâr et alt for stort râderum. Dette mærkes på mange punkter i Kiristian VIIls regering; det ses at han ikke mere var nogen ungr mand, da han besterg tronen; han forstod ikke at tie $n g$ overveje $i$ tavshed for da at handle med udelt kraft; alt for nange indriedes i hans betankeligheder, han ønskede si at sige at hore alles mening, f $f(x$ han tog sin beslutning.

Men nâr man lægger vagt herpa, liggrer det spurressmål dog nær, om han da overhoved iklke kom til at handle ogr om hans handlinger var xngstelige, ufullhiome og vaklente, om han viste mangel pâ mod $i$ udforelsen af hvad han havde besluttet? Intet af dette vil med rette kunne påstâs. Hverken den danske eller den slesvigholstenske presse skal rose sig af at have haft nævnerærdir indflydelse pä hans handlinger, skont begge angreb ham skånselslost; overfor Fredrk VI. havdede hau i en arræklie sine afvigende liberale anskuelser, og hvor lidt embedsmændene formåede overfor hans omfattende og grennemgribende reformarbejcle i administrationen er bekendt nok. Hins optræden efter det abne brevs udstedelse riser 
sandelig ingen mangel pia personligt nod, ng $\mathrm{i}$ åringer at være en upopulær mand i sin hovedstad, stadig genstand for de voldsomste udfald og forhánelser, urlen at tabe ligevæuten og enten give efter eller misbruge sin ubegræusede magtfuldkommenhed, er ikke enhver given. Nâr man stadig har villet anfore hans optræden i Norge 3.814 som bevis pa halvhed og umandighed, da har den nyere tids klarere opfattelse af hine begivenheder forlængst renset hans minde i den henseende. Hvad han rovede ved at modsiatte sig Kieler-fredens udforelse var langt mere, end hrad han liumle tænke på at vinde; forsøget på at havde Norges selvstændighed var et voveligt og ridderligt skridt, der meget let kunde have kostet ham også Danmarks krone, og det anerkendes vel nu fra alle sider, at han ved sin oltræden dengangr indlagde sig en uforgæangeligr fortjeneste af det norske folk. Nar man saidan uden videre har brudt staven over hans nedlaggelse af kronen, da er det kun et af de mange tern pả, hvor umodne vore domme om de store politislie begivenheder er. På helt middelalderlig vis vil vi kun se helten i len, "somi kunde ikke vige“, uden hensyn til alle de givne betingelser, uden forstielse af verdens faktiske magtfordeling. Fn fortsat modstand fra prinsens side vilde dengang ufejlbarlig have fort ham selv i ulykke og fremkaldt et almindeligt frafald i Norge med al den skansel or de ulykker, som deraf vilde være fulgte. Han havde ved sin resolute handling onnaiet for folket, hrad der kunde opnis.

Historiske personer må imidlertid finde sig i slige domme af dem, som aldrig selv har stảet overfor store forhold; i blarle og skrifter kan meget siges og gentages, som kun vidner om r'nge forstaelse af hvad den enkelte 
i det givne øjeblik kan udrette. Værre er det, når mænd, som selv har prøvet at bære et ansvar, fælder nedsættende domme om samtidige personer. $O g$ det kan ikke næotes, at dette er tilfæeldet for kong Kristian VIII's vedkommente. Jeg skal kun nærne en enkelt af hans angribere, en af de mest ansete mænd blandt hans santidige, professor H. N. Clausen. Ogsii han bebrejler ham mangel på mandig fasthed, både i Norge og Danmark. Og hvad har si Clausen selv udrettet i de isr, da han pâtog sig et medansvar for rigets styrelse? Han trådte ind i ministeriet i November 1848 for her at representere den mådelioldne frihed og den nationale sag, og han sad der til Juli 1851, da så at sige alt det var opgivet, som havde stảet pá hans program. Han holdt på en deling af Slesvig efter nationaliteterne, en lempelig og retfærdig ordning af sprogforholdene på grundlar af befolkningens ønsker, og dog gled han med de andre orer imod helstaten og han gjorde intet for at afværge en ensidig og voldsom afgørelse af sprogsagen, som han endog senere forsvarede med den :torste iver. Han var med at forelægrge og få vedtaget. en grundlov, hvis hele gruncllag var vidt forskellig fra hvad han havde udtalt sig for "ved tronskiftet". Jeg nævner ikke dette for at belrejde Clausen det; thi forholdene var selvffilgelig meget stærkere end han og det kan have været det eneste rette, at han blev i statsrådet det længst mulige for på hvert punkt at forfægte sine anskuelser. Men hrad der vel vil kunne bebrejdes ham er, at han ikke under denne virksomhed fik en anden og rigtigere målestok for, hvad magthaverne $i$ en lille stat formair og hvilke hensyn der må tages red bedømmelsen af deres handlinger.

Kristian VIII. havde ved sin alder og de rige politiske 
erfaringer, han havde indsamlet ogsai som opmærksom iagttager, et meget vasenligt fortrin for den opposition, der med stigende hidkighed kastede sig i kampen mod ham. Han havde lart at vente or give tid, for da at benytte det rette ojeblik til en afggrende handling. Alt tidlig beternede han den norske forfatning som "hastværk" ogtidlig bad han de danske statsmænd betænke, at der engang matte gives en forfatning og at man derfor maitte gore sig rede for dens form og måde; da det så blev til alvor, uforberedt som alting var, beklagede han gang efter gang oy med fuld frije, at de vigtigste bestemmelser var fremgiele af et lignende "hastrærk". For oppositionen syntes dette hensyn ikke at have nogen betydning; "bare gesvindt!“ var omkværlet $i$ alle dens krav. Silledes i de konstitutionelle, således ogs:å i de nationale spørgsmål. Ikke en jærn og naturlig udvikling, men en kuldkastelse af det i arhundreder nedarvede mitte der til. Enevælden, der med alle sine store skyggesider havde fremmet vor samfundsudvikling i retning af borgerlig lighed og sikkerhed $i$ alle offenlige forhold, matte brat afloses af folkets selvstyre; forholdet til Sønderjylland og Holsten, der hvilede på et girundlag af arhundreders indholdsrige historie, skulde ordnes efter principer, som naturnodvendigt mitte fremkalde de stik modsatte fra modsat side. Da besindige frihedsmand som David, Ussing og Ørsted mente at burde holde igen og støtte kongen i hans bestræebelser, litgdes de for had som "reaktionære". Vi véd hvad dette hastværk forte til, da begivenhederne i 1848 bragte oppositionen til magten. Få dages overvejelse i Martsministeriet liuldkastede en menneskealders arbejde med at finde betryggende former for statslivets friere udvikling, og vi kom 
ind i den "vandring i ørken," som Orla Lehmann phistod at have forudsét vilde vare $40 \mathrm{ar}$, livad den ogsá xrlig har gjort. Nationalt fik vi en sprogorining, som blev blast omkuld af det første vindstød, da befolkningen blev overladt til sig selv, og et politisk vilderede, som gjorde at ingen vidste ud eller ind, da afgørelsen skulde træffes.

Det vil vanskeljgt kunne næotes, at liristian VIIl's virksomhed $\mathrm{i}$ den henseende stir anderledes helstobt on vel begrundet. Hvad han udrettede i national henseende i de år, han bar lironen, var ikke blot af gennemgribende betyduing, men stod orsi sin prove i den folgende tid. Den retfordighedshandling, der li̊ i sprogreskriptet, havle ingen tilligere konge laft øje for eller magtet; den blev ulfort med kraft, gennemfirt med fasthed $\mathrm{og}$ opretholdt indtil alle bojecle sig for den. Det er affelitation at gone ophavelser over, at der indfortes visse lempelser for en overgangstid, og det viser kun, hvor umodne vi var i alle offenlige anliggenders droftelse. Det er i foredrarget omtalt, hrorlerles kongen selv overbeviste sig om sine befalingers efterlevelse, og det er et ubedrageligt tegn fá, hror sejrigt de var trangte igennem, at den revolutionære slesvigholstenske stæuderforsamling i 1848 ilke rovele at rore rad dem, men vedtog som grundlev, at "sprogrenes greldende brug i lirke og skole, retspleje og forvaltning er garanteret" (s 24).

Ud fra dette faste grundlag gik Kristian VIII. videre. Han forberedte sprogrgransens Hytning i overensstemmelse med folkesproget, særlig til kgbstaderne, sprogenes ligeberettigelse i regreringen og kollegierne, i standersalen og red overretterne; han besluttede oprettelsen af danske lacreanstalter og begunstigede udviklingen af den danske 
befolknings selvarbejile for sin nationalitet ved bogsamlinger, dagblade og folkehojskoler (foruden den i Rodding pittanktes der 1847 en anden i Ullerup).

Ilaske har de senere år forholdsvis langsommere udvikling i de offenlige forhold bidraget til, at vi nu vil kunne domme mere retfardint om dette udbytte af otte ârs arbejde jå bar bund. Sat at det var blevet fortsat i sanme and, med samme forening af varsomhed og kraft, uden ydre afbrydelser, mon vi da iklie i lobet af mindre end en menneskealder vilde være kommen til en fuldt retfardig losuing af sprogsagen, en fra alle sider anerkendt liweberettigelse mellem de to nationaliteter? og var en menneskealder for meget til en sa gennemgribende omdannelse af hele det offenlige liv? Hvorledes har ikke de forurettede nationaliteter $i$ andre lande mattet kæmpe $i$ lange år, inden sejrens frugter modnerles, -- i Bomen, i Finland, og rundt omkring i Evropa!

Det er et markeligt fejlsyn, at Slesvigholstenerne sliulde have været sarlin slette mennesker, der mere end andre vilde forholde deres medborgere en naturlig ret. Pâ samme naide, som det skete her, har de nationaliteter, der sad incle med det nedarvede herredomme, overalt modsat sig folkesprogenes krav på ligelıerettigelse. Der gâr tid med at overhevise, finde de rette former og de rette grænser. Ogr selve den forhen forurettede og derfor vamrogtede follelighed skal have tid til at blive sig hevidst, blive klar over sin trang, tilegne sig sit modersmail i hele dets omfang, det forædlede skriftsprog. Først da har kravet pa ligeberettigelse sin hele vagt og sin nolvendige rod. Ingen vil kumne pasti, at dette var tilfoldet i fyrrerne i Nordslesvig. Koblstaderne var vitterlig tysksindede; de 
indgar i 1817 adresser on at forblive sammen med Holsten og de gentog det ved tronskiftet 1839; da Hjort Lorenzen 1841 blev valut i Sonderborg, var det med 28 stemmer af $136,0 \mathrm{~g}$ hans program var Slesvigs selvstandigherl overfor Danmark og Holsten. Han og alle hans renner ulenfor bondestanden skrev tysk til hinanden, bade dengang og senere. Bondestanden i Nordslesvig var uden nogen somhelst forbindelse med sine standsfaller i kongerigret, This Stenholt i Rassted og hans dansktalende vælgere bad om sprogreskriptets opliævelse. Flor beliagede sig fra Rødding bittert over bondernes "slovhed“. Som i foredraget omtalt, møite alle de danske deputerede 1846 uden, på Nis Lorenzen nær, at gøre brug af deres ret til at tale dansk. Forst langt senere, efter at have oplevet store trængsler; kunde den nationale sag bryde sâledes igennem, at den nordslesvigske befolkning larte fuldtud at fole sig som danske, $i$ et $o g$ alt af samme natur og med de samme lirav til det andelige liv som det wrrige folk. $\mathrm{Og}$, som alt næunt, dette er ikke særligt for denne befolkning, det er en falles erfaring i hele den civiliserede verden, hvor nationalitetssporwsmalet er trongt frem. Hvis kong hristian VIII. derfor blindt havie fulgt Hjort Lorenzens og Orla Lehmanns tilkkyndelser i den danske sag i Nordslesvig, vilde han ikke blot uden nytte have pâskyndet den katastrofe, som de store verdensberivenheder 1848 fremkaldte, men som ellers rimeligvis kunde være undgiet; men han vilde ikke usandsynligt have udsat sig for en modstand eller et frafald i selve Nordslesvig, som vilde have tilfojet den sag, han ønskede at fremme, en ubodelig skate.

Jeg skal endnu kun et ajeblik dræle red det tilsyne- 
ladende omslag i kongens politik i foritret 184:, der beternes ved prinsen af Nor's ulnarnelse til statholder, en begivenhed, som jo bestandlig girres til genstand for de bitreste bebrejdelser og som jeg i mit foredrag ikke fanit anledning til i enkelthederne at gøre rede for.

Da kong Kristian VIII. i December 1839 tiltri̊dte regeringen, forefandt han et statirăd, der foruden den 66årige Rantzau-Breitenburg, som faktisk trak sig tilbage, bestod af fem medlemmer af den respektable samlede alder af 348 år; Vilhelm Moltke var 54 âr, Otto Moltke og Lirabbe 69, Stemann 76 og Møsting 80 år. I foråret 1842 var de samme mænd bleven godt to år ældre. Imidlertid havde kongen arbejlet ufurtrødent pa statens opkomst; der var indfort talrige besparelser, alministrationen var gjort simplere og lettere, embedsmændenes antal indskrænket og deres Iøn forbedret, hærens reform bragt sin gennemførelse nær osv. Men det kunde ikke være andet end at det gamle statsrid, hvis fleste medlemmer rar stivnede i den gamle konges til, i mangt og meget tyngede

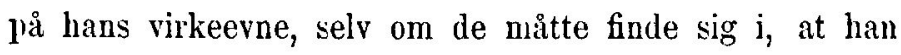
gik sine egne veje og ikke som kong Fredrik VI. lod dem råde. Men det var naturligt, at han benyttede et gunstigt wjeblik til en fornyelse af radet, siden nan af pietet mot sin foryænger havde undladt straks at foretage forandringer. Dette øjeblik kom, da Iøøsting i Januar 1842, 60 år efter sin indtrædelse i statstjenesten(!) søgte afsked; han døde irret efter. Der kan ingen tvivl være om, at kongen straks tænkte pi at erstatte ham med Ørsted, generalyrokurør i det danske kancelli og langt tilbage den mand, han som prins folte sympati for som bærer af mere liberale tendenser. Idforrelsen heraf opsattes dog indtil videre, måske ford 
kongen vilde rålføre sig med sin svoger prinsen af $\mathrm{N} k r$, som kort efter blev kaldet herover. Det er for nylig bleven oplyst fra tysk side (af Treischke), at prinsen undervejs betroede en ven, at lian vilde soge statholderembedeí, ng i mit foredrag har jer næunt, at han for longen gjorde galdende, at der burde optages en mand fra hertugdømmerne i statsrådet. Kongren gik ind herpå og valgte Heinrich Reventlov-Criminil i det tyske kancelli, altsa i stilling swarende til Ørsted. Da han meddelte sin beslutningr om at udnavne prinsen til statholder i statsridet, fraridede Otto Moltke det og søgte et par dage efter sin afsked. Kongen selv pâstår $i$ et brev, at den virkelige grund var mandens svaghed og mangel pî evne til mere at bestyre sit embed, og vist er det, at han alt mange år fwr, 1527, erklarede sig for ude af stand til fuldt ud at varetage sine pligter. Statsradet tabte næppe noget ved hans udtrædelse, og surrlig havde laan $\mathrm{i}$ det nationale spørgsmål aldrig for alvor gjort fælles sag med prinsen, da det gjallt om at hindre Slesvigs tilknytning til Holsten; han lavde som president $\mathrm{i}$ det tyske kancelli helt ladet sig beherske af den antidanske Hopp, som Kristian VIII. straks efter sin tronbestigelse fjernede ved at gore ham til formund $i$ overapuellationsretten.

Fi dage efter at Otto Moltke havde meddelt kongen sin beslutning at soge afsked, greb denne lejligherlen til ligeledes at fjerne udenrigsministeren Krabbe Carisius, for derefter at give Criminil hans portefeuille; samtidig udnæerntes den erfarne Dankwarth til direktor i det udenlandske departement, en hidtil ukendt stilling, som gav kongen lejlighed til at danue sig en mere alsidig mening om de diplomatiske forhold. Krabbe, der fra Fredrik VI's 
Kung Kristiun VIlI. oy den danske sag i Nordslesvig. $\quad 281$

tid vall vant til at style de ulenrigske sager pil egen hând, - de refereredes som regel ikke i statsratut, men for kongen personlig - var sia uforsigtig ved et referat $i$ heftige uultryk at belnejole kongen, at han havde truffet en bestemmelse m. h. t. de i Helsingor fyrte forhandlinger med sverige, i modstrid med hans râl, og han slog pâ, at han under disse omstrendigheder var overfludig og helst mâtte gä. Da kongen ikke svarede herpâ, fortsatte han imicllertid sit referat, men dicen efter minclede kongen ham om, at han havile sogt sin afsked og at den ikke ville hlive nagtet ham. Megret mod sin vilje kom Krabbe siledtes til at gâ af; men senere hed det sig, at ogsí han havele sogt sin afsked af mistillid til statholderen.

Eulnu kitn det nownes, at Heinrich Criminils broder Josef, antmand i Rensborg, blev kaldet til Kobenhavn for at overtare prosidiet i det tyske kancelli, men uden det siede i statsridet, som prinsen af Nor gentagne gange søgte at skatf'e ham. Kongen, der ikke tidligere havde kendt ham, kom snart under vejr med, at han var en „notorisk Slesvigholstener", or hans indflydelse blev aldrig stor. Broleren derimod kalder Grsted vor dygrtigste udenrigsminister siden Bernstorfts dagre, og vist er det, at han med ualmindelig dyrtighed or ubestridelig lojalitet tjente kongens politik, hvis mâl or midler ofte afveg ikke lidet fra, hvad han ansï for det rette. Avgustenborgerne nævnede ham blandt dem, der ved at give efter for kongens ovprlegne personlighed og gore ham til vilje var gået tabt for hertugdømmerne ogr var bleven en "brudt mand“.

Ingen vil si̊ledes kunne nægte, at forandringen i statsrådets sammensætning $\mathrm{i}$ Marts 1842, så vidt man kan skønne, var den efter forholdene bedst mulige, ligesom en 
forandring var en bydende nodrendighed; ned undtagclse af den hojt ansete on grundlanske Stenunn var alle medlemmer nu mand $\mathrm{i}$ leres fulde kraft. At der ved den samtidige hesattelse af embederne som statholder og som prasident i det tyske kancelli var giort et alvorligt forsogr pí at drempe den voksende bevorgelse $i$ den tyske del af hertughommerne, vilde let vare tankelsst at behrejle kongen; at det ikke lykkedes og at de to mænd fire ar efter matte atskedires, var en politisk erfaring, som havde sin betydning. Men den sandhed, at det i det politiske liv kan være onskeligt, ja nolvendigt at prove forskellige muligheder for ad erfaringens vej at skidile frem med storre sikkerhed, isterlenfor at overspringe mellemledilene og lade tvivl om de starkere brydningers nodvendighed fai riderum, fordi narligrende urveje iklie er forsugte, - denne sandhed hat altid haft vanskelig ved at komme frem hos os, og den var i 1842 endnu kun gâct op for sâle fï.

Endnu kun et par ord for at afværre en máske nær-

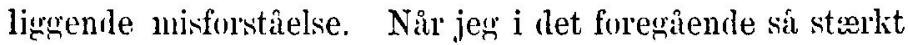
laa fremhret, hvad der taler til gunst for kongr Kristian VIII. og is ax til forswar for hans nationale politik, da har jeg ikke derved villet rette noget angreb på den opposition, som stod overfor ham, fordi den sogte at drive ham frem; jeg har kun villet angribe dens ensidige opfattelse og fremstillingr af kongen. Det var i sin orden, ja det var en lykke, at denne opposition fandtes, og jeg har jo i mit foredrag fuldt ud indrommet den en ligeberettiget plails ved silen af longen. Hvad vilde der vare bleven af den danske sag uden mand som Lavrids Skau, Kuch, Flor, Pauken og den uforglemmelige Iljort Lorenzen, for blot at nevne dem, der virkede i Sonderjylland! Havde kongen 
Long hiritian VIII. og den danske sag i Nordslesvig. 283

ret $\mathrm{i}$ at fare med lempe, sia havde de ej mindre ret $\mathrm{i}$ at trange pa og holle hevagelsen $i$ live on $i$ fremgang. Mailet må stilles hujt og klirt, nâr et folk skal vækkes af dvale. Men ingen af disse minnd bliver mindre, fordi vi også viser retfiridighed mod en konge, hvis ansvarsfulde opgave det var at jærne vejen og sorrge for dens sikkerhed. skulde det imidlertid være for tidlig nu at vise denne retfærtlighed, - nuvel, sia ma det forbeholdes en senere slixgt.

Men mon det skulde rare for tidlig?

Den 29. Uktoler. 